\title{
THE COMPULSORY LICENSE SYSTEM OF THE UNIVERSAL COPYRIGHT GONVENTION*
}

\author{
7 HE Universal Copyright Convention, ${ }^{1}$ promulgated by UNESCO \\ in 1952 and ratified at present by the United States ${ }^{2}$ and a sufficient \\ number of other states to bring it into effect, ${ }^{3}$ is an attempt to supple-
}

* This comment was adapted from a paper entered by Gerald R. Gibbons in the Nathan Burkan Memorial Competition at Duke University.

${ }^{1}$ Preparation for the Convention began in 1947 with an extensive study of the copyright laws of the world. In 1950 a committee of experts met in Washington, D.C., to solicit suggestions from various nations and to frame a tentative draft. The final draft was then prepared and signed at Geneva on September 6, 1952, by the United States and thirty-five other nations. For a record of the Convention proceedings, see r-7 UNESCO COPYRIGHT Bull. (r948-r954). See also 2 Bull. Copy. Soc. 82-115 (1955).

The literature concerning the Convention is substantial, but none of the commentators has discussed the problems arising out of the article dealing with translation rights. For other aspects of the Convention see Chediak, The Pogressive Development of World Copyright Law, 42 AM. J. INT'L L. 797 (1948); Finkelstein, The Universal Copyright Convention, 2 AM. J. CoMP. L. 198 (1953); Henn, The Quest for International Copyright Protection, 39 CORNELL L.Q. 43 (1953); Honig, International Copyright Protection and the Draft Universal Copyright Convention of UNESCO, I INT'L \& CoMP. L.Q. 217 (1952); Kampleman, The United States and International 'Copyright, 4I AM. J. INT'L L. 406 (1947); Sherman, The Universal Copyright Convention: Its Effect on United States Law, 55 CoLUM. L. REv. 1137 (1955); Schulman, Another View of Article III of the Universal Copyright Convention, 1953 WIs. L. REv. 297; Schulman, International Copyright in the United States: A Critical Analysis, r 9 LAW \& Contemp. Prob. I4I (1954); Warner, The UNESCO Universal Copyright Convention, 1952 WIs. L. Rev. 493. Notes, The Work of UNESCO on Copyright, 43 AM. J. INT'L L. 343 (1949); International Copyright and Musical Compositions, 3 DE Paul L. Rev. 52 (1953); American Copyright in the International Picture, 34 B.U.L. REv. 478 (1954); Seither, UNESCO: New Hope for International Copyright, 6 A.S.C.A.P., CopYright LAW SYMPOSIUM 74 (1955).

2 President Eisenhower submitted the Convention to the Senate on June ro, x953, for its advice and approval. 99 CoNG. REc. 6348 (1953). The Senate approved it on June 25, 1954. roo Conc. REc. 8945 (1954). Implementing legislation, H.R. 6616 and S. 2559, 83 d Cong., rst Sess. (1953), was passed and approved by the President on August 31,1954 . The instrument of ratification was signed November 5, 1954, and deposited in Paris on December 6, 1954.

${ }^{3}$ The Convention, under article IX, was to become effective three months subsequent to the deposit of twelve instruments of ratification. Monoco, on June 16,1955 , became the twelfth state to deposit its ratification. N.Y. Times, June $x 7$, 1955, p. x, col. 7* As of June $\mathrm{r}$, 1956, the Convention had been ratified by: Andorra, Cambodia, Chile, Costa Rica, German Federal Republic, France, Haiti, Holy See, Israel, Japan, Laos, Luxemburg, Monoco, Pakistan, Philippines, Spain, Switzerland, United States. Cf. 
ment $t^{4}$ the existing pattern of international copyright law ${ }^{5}$ with a uniform system of minimum protection ${ }^{6}$ acceptable to all countries. ${ }^{7}$ The primary purpose of this uniform system is to reconcile the demands of author protection with the urgent need for cultural diffusion among the less literate nations of the world. ${ }^{8}$ As would be expected, the most

Sherman, The Universal Copyright Convention: Its Effect on United States Law, 55 Colum. L. Rev. $\mathrm{Ir}_{37}$ n. 2 (1955).

"The Convention does not abrogate any multilateral or bilateral copyright relations existing at the time it becomes effective as to any state.

'Existing international copyright relations are dominated by two mutually exclusive treaty systems, the Berne Union and the Pan-American treaties. The Berne Union was founded in $r 886$, and has experienced five successive revisions: Paris (1896), Berlin (1908), Additional Protocol of Berlin (1914), Rome (1948), Brussels Conference (1948). With the principal exceptions of Russia, China, the United States, and the Latin American republics (except Brazil), most of the major nations of the world are members of the Berne Union, the predominant characteristic of which is its high standards of author protection. See Schulman, supra note $r$, at 300 . See generally, Fisher, The Berne Union (i949); i Ladas, The International Protection of Literary and ARtistic Property (1938).

While the Berne Union is open to accession by all states, the Pan-American treaties are limited to ratification by the states of this hemisphere. This latter system is comprised of separate, overlapping conventions: Montevideo (1889), Mexico City (1902), Rio de Janerio (rgo6), Buenos Aires (rgro), Havana (r928), Washington (r946). Of these, the United States has ratified the Buenos Aires and Mexico City Conventions. As the Buenos Aires Convention is the only one to receive wide acceptance, it is the most important of the Pan-American treaties. See CANYes, ColduRn AND PIAZZA, COPYRIGHT PROTECTION IN THE AMERICAS (2d ed. 1950); I LAdAs, op. cit. supra at 635-79. See also, Ladas, Inter-American Copyright, 7 U. PITT. L. Rev. 283 (1941); Note, The Inter-American Copyright Convention: Its Place in the United States Copyright Law, 6o HARv. L. REv. 1329 (1947).

${ }^{\circ}$ While the basis of the Convention is that of lex fori and national treatment of works published in a signatory state, the law of each signatory state must grant to foreign copyright the minimum protection of the treaty. See Crewe, National Treatment as the Basis for a Universal Copyright Convention, 3 UNESCO COPYRIGHT BuLl. no. 1, p. 3 (1950); de Sanctis, $A$ Universal Convention and a Minimum of Protection, id. at $7 x$; Tannenbaum, The Principle of National Treatment, 2 Bull. Copr. Soc. 855 (r955).

7 The standards of author protection in a convention agreeable to all countries were necessarily low. Since the standards of the Berne Union are high, it was feared that some of its members, upon ratification of the UNESCO Convention, would denounce the Union. As a precautionary measure, the UNESCO Convention provides that, as between Berne signatories, the Union must apply, and that if any state, after January $x, 195 x$, renounces the Berne Union, that state will not be eligible for protection under the UNESCO Convention.

${ }^{8}$ As underdeveloped countries have no substantial author class to protect, there is correspondingly little advantage to be gained from membership in a copyright convention by these states. However, despite the seeming advantages of refusing to recognize foreign copyright, such states probably do not seriously favor literary piracy, but 
acute conflict of interests between states of diverse cultural attainment arises in connection with the protection of the right of translation, which is clearly an author's only international claim of any substance. The culturally absorbing countries quite understandably feel that protection of foreign copyright is feasible for them only if there is some restriction on this exclusive right of the author. ${ }^{9}$ The publication of a local translation in such countries is ordinarily very expensive, since a translator must be paid and markets are thin. ${ }^{10}$ Such difficulties, when coupled with the necessity of securing the author's permission and paying him the royalties he demands, have frequently discouraged the acceptance by these countries of any extensive international obligations to protect foreign copyright. ${ }^{11}$

The UNESCO Convention sought to compromise these competing interests of the culturally producing and absorbing states by the unprecedented ${ }^{12}$ compulsory license system of article V-the keystone article of the treaty. ${ }^{13}$ Under this compromise plan, the author's exclusive

rather desire to acknowledge the responsibilities of participation in an orderly system of international copyright protection. Because their membership would be largely a concession, however, they possess substantial bargaining power.

${ }^{\circ}$ See Mendilaharzu, The Bases of a Universal Convention on Copyright, 3 UNESCO COPYRIGHT BuLl. no. I, p. 35 (1950); El-Tanamli, The Right of Translation and the Public Interest, Id. at 88.

${ }^{10}$ See del Castillo, Copyright and the Use of Foreign Works, 1d. at 13.

${ }^{11}$ The original Berne Convention of I 886 granted only a minimum period of ten years' protection to translation rights. This was extended by the Berlin Revision of 1908 to the full term of protection granted the author's other rights-the life of the author and fifty years. However, a number of states ratified the revision subject to reservations concerning translation rights. LADAs, op. cit. supra note 5 , at 386 . The Washington, Havana, and Buenos Aires treaties among the Pan-American Conventions, while they also recognize the right of translation, do not set any minimum period of duration for protection of translation rights.

${ }^{12}$ No previous international copyright convention has adopted a compulsory license system. Recent legislation in several countries, however, was a harbinger of the conditions precedent to the licensing provisions in article V. For example, a Mexican statute of 1948 limits the right of translation to three years unless the author has authorjzed a translation in Spanish. See Warner, supra note $\mathrm{r}$, at $498 \mathrm{n.} 22$.

${ }^{13}$ The complete text of article $\mathrm{V}$ is as follows:

Copyright shall include the exclusive right of the author to make, publish and authorize the making and publication of translations of works protected under this Convention.

However, any Contracting State may, by its domestic legislation, restrict the right of translation of writings, but only subject to the following provisions:

If, after the expiration of a period of seven years from the date of the first publication of a writing, a translation of such writing has not been published in the national language or languages, as the case may be, of the Contracting State, by the owner of the 
right of translation is reaffirmed; but it is further provided that any contracting state may, by domestic legislation, restrict that right in the following manner: ${ }^{14}$

If, after the expiration of a period of seven years from the date of the first publication of a writing, a translation of such writing has not been published in the national language or languages, as the case may be, of the Contracting State, by the owner of the right of translation or with his authorization, any national of such Contracting State may obtain a non-exclusive licence from the competent authority thereof to translate the work and publish the work so translated in any of the national langunges in which it has not been published. ...

right of translation or with his authorization, any national of such Contracting State may obtain a non-exclusive licence from the competent authority thereof to translate the work and publish the work so translated in any of the national languages in which it has not been published; provided that such national, in accordance with the procedure of the State concerned, establishes either that he has requested, and been denied, authorization by the proprietor of the right to make and publish the translation, or that, after due diligence on his part, he was unable to find the owner of the right. A licence may also be granted on the same conditions if all previous editions of a translation in such language are out of print.

If the owner of the right of translation cannot be found, then the applicant for a licence shall send copies of his application to the publisher whose name appears on the work and, if the nationality of the owner of the right of translation is known, to the diplomatic or consular representative of the State of which such owner is a national, or to the organization which may have been designated by the government of that State. The licence shall not be granted before the expiration of a period of two months from the date of the dispatch of the copies of the application.

Due provision shall be made by domestic legislation to assure to the owner of the right of translation a compensation which is just and conforms to international standards, to assure payment and transmittal of such compensation, and to assure a correct translation of the work.

The original title and the name of the author of the work shall be printed on all copies of the published translation. The licence shall be valid only for publication of the translation in the territory of the Contracting State where it has been applied for. Copies so published may be imported and sold in another Contracting State if one of the national languages of such other State is the same language as that into which the work has been so translated, and if the domestic law in such other State makes provision for such licences and does not prohibit such importation and sale. Where the foregoing conditions do not exist, the importation and sale of such copies in a Contracting State shall be governed by its domestic law and its agreements. The licence shall not be transferred by the licencee.

The licence shall not be granted when the author has withdrawn from circulation all copies of the work. 5 UNESCO COPYRIGHT Bull., no. 3, p. 32 (1952).

${ }^{14}$ See note 13 sipra. 
Because of its experimental nature, this article raises a number of constructional problems which will be resolved initially by the implementing legislation of the signatory states, and perhaps ultimately by the International Court of Justice. ${ }^{15}$ It is presently uncertain, of course, what the eventual disposition of these problems will be; but an examination of the various possibilities may at least disclose the extent to which the compulsory license system will serve the adverse interests of cultural diffusion and author protection.

\section{The Conditions Precedent: No Authorized Translation in the National Language}

Under the above quoted provision, a compulsory license may be granted only after seven years ${ }^{16}$ from the date of the first publication. ${ }^{17}$

\footnotetext{
${ }^{15}$ Since the treaty does not abrogate the usual international law rule requiring the "exhaustion of local remedies," interpretation will first devolve upon the local governments concerned. If they cannot resolve the difficulties, article $\mathrm{XV}$ of the Convention provides for the obligatory jurisdiction of the International Court of Justice. The complexity of the problems which are likely to arise and the fact that claims are not likely to be large would recommend a simpler procedure for settlement. The French Government, in fact, proposed that a commission of three arbiters be set up to deal exclusively with the problems arising from article $V$. While this suggestion was not incorporated into the text of the Convention, such a method of settling disputes is undoubtedly open on the intergovernmental level; and experience in the administration of the article may favorably dispose the states in future revisions of the treaty, to make obligatory such a means of settlement at a level lower than the International Court of Justice. See 6 UNESCO Copyright BuLl. no. I, p. 2 I (I953), for the text of the French proposal.

${ }^{10}$ The recommended draft of $195^{\circ}$ contained two articles concerning translation rights, a draft article and an annex. Both dealt with the same subject matter, but in different terms. The draft article left open the duration of the exclusive right of the author to dispose of the translation rights, but the annex provided for a period of twenty years' protection. The states split badly on this question, some recommending as little as three years' minimum protection and others as inany as twenty. Many favored a period of ten years. The compromise of seven years was submitted in a combined proposal by Italy, Mexico, the United Kingdom and the United States. See 6 UNESCO COPYRIGhT Bull. no. I, p. 2 I (1953).

Because this relaxation of protection as to the right of translation was based primarily on the educational needs of underdeveloped states, perhaps the treaty should have provided a lesser period of protection for "educational" works as opposed to other writings. Several states, in fact, forwarded such a proposal, but the distinction was discarded because of the administrative difficulties involved in drawing a line of demarcation between the categories. While treating all writings equally will doubtless avoid confusion in application of the article, still there are some tenable arguments in favor of the proposed distinction. For example, certain types of works, especially scientific books, tend to become obsolete over a short period of time and as to them a shorter period of protection would better serve the policy of this article.

${ }^{17}$ The words "first publication" raise the question as to whether the article applies
} 
Even then, however, such a license may be granted only if an existing translation of the writing 18 "has not been published ... by the owner of the right of translation or with his authorization." While this provision clearly indicates that an authorized translation in a particular language will operate as a bar to future compulsory licensing in that language, a question remains as to whether a compulsory license will have the same effect. On the one hand, it might be argued that it should, since a compulsory licensee is "the owner of a right of translation," and since the purpose of the article to facilitate access to translated materials might be adequately served if there is any translation, either authorized or licensed. On the other hand, however, the fact that the term "owner of the right of translation" is used throughout the article to designate the author ${ }^{19}$ as a party separate and opposed to the license applicant seems to indicate that the drafters did not intend the compulsory licensee to be regarded as such. ${ }^{20}$ This position, that a compulsory license will not alone bar subsequent licenses, would seem to be more consistent with the purpose of the article, which is to extend only such protection to the author after the first seven years as he may claim by affirmative action. At any time, either before or after the issuance

to works now in print or only to those subsequently published. As article VII extends protection retroactively to all works "not in the permanent public domain" of the state of original copyright, the licensing provisions would extend by implication to works previously published, since the first sentence in article $\mathrm{V}$ applies the article to "all works protected by this Convention." As a result, upon the passage of a licensing statute by a contracting state, works published seven years before that date could be translated under license immediately.

${ }^{18}$ It should be noted that the license provisions apply only to "writings." In as much as article I provides that the treaty shall apply to "writings, musical, dramatic and cinematographic works," it is arguable that the reference to "writings" in article $V$ excludes the other enumerated categories; but, in certain respects the categorics overlap. Sheet music and the lines of a play are "writings" as well as "musical" and "dramatic" works. Because of this obvious overlapping, a technical use of "writings" was probably not intended; and, thus, sheet music and plays would be subject to licensing. However, since the article only extends to the licensee the right to "translate and publish," a performance of a song or play would not be permitted. The status of cinematographic works is also debatable; but because the sound track of a moving picture is not written, the licensing provisions would not scem to apply. Cf. Dubin, Universal Copyright Convention, 42 Calif. L. Rev. 89 (1954).

${ }^{18}$ For convenience, the term "the author" is used in this text rather than the more cumbersome term "owner of the right of translation," despite the fact that very often the author and the owner of the right of translation are not the same parties.

${ }^{20}$ In addition, the right of the licensee to translate is a highly restricted one in that $i \hat{t}$ is nonexclusive and nontransferable. See notes 36 and 37 infra. 
of a compulsory license, an author may bar all subsequent ${ }^{21}$ licenses in a particular language by authorizing a translation in that language.

The authorized translation which will bar subsequent licenses must have been published in the "national language or languages" of the licensing state. ${ }^{22}$ Since a number of countries have, or may in the future declare more than one national language, ${ }^{23}$ it becomes important to know whether an existing authorized translation in one national language will bar a license to translate into a second national language. While, arguably, the wording of the article is ambiguous in that "or languages" could mean either one of several languages, or all of them, the French and Spanish versions of the draft clearly indicate that if such a translation exists in one national language, a license cannot be granted for another national language, although no translation exists in the second language. ${ }^{24}$

While the problem, as it relates to the intention of the drafters, may thus be settled, the restriction has little to commend it as an original proposition. Since the purpose of the article is to allow greater access to

${ }^{21}$ There is no provision in the article for any termination of a license once issued; and such a license would seem to be in the nature of a vested right, as expenses and commitments are likely to have been made in reliance on the continuing validity thereof. Therefore, it would seem that licenses could not be terminated under the treaty by the later publication of an authorized translation.

${ }^{22}$ See note 13 supra.

${ }^{23}$ The Rapporteur Général, Sir John Blake of the United Kingdom, in his report concerning article V, noted that it was "understood" that a state could determine which were its national languages for the purposes of the Convention. 5 UNESCO COPYRYGHT BULL. no. 3, P. 54 (1952). This was in response to an inquiry by the Indian representative, who was concerned with the legality of declaring local languages of his country as "national languages" for Convention purposes. The history of the article does not indicate an intent to go behind a declaration of a state as to which are its "national languages," as for example, by questioning whether a declared language is really used for official state documents. However, an implied limitation on this declaratory power might be deemed to exist if a state declared a language which only a very small number of its inhabitants customarily read.

24 The French draft reads "dans la langue nationale ou, le cas échéant, dans l'une des langues nationales d'un État contractant." The Spanish draft is also clear on this point: "o en una de las lenguas nacionales de un Estado contractante." Although article XVI of the Convention specifies that the drafts in each of the three languages are to be equally authoritative, the English draft does not conflict with the other two, and its ambiguity is clarified by the wording of the other two drafts. This ambiguity in the English draft is especially curious in that the original English draft and its annex were both clear on this point: "or in the case of a contracting State having more than one national language, into any one of those languages." 4 UNESCO COPYRIGHT BULL. no. 3 , pp. 9 , $15($ (95x). 
translated materials in underdeveloped states, and since the usual reason for having more than one national language in a state is that large portions of the population read exclusively one of the several languages which are spoken in that state, translation into only one of several national languages will often insufficiently advance this purpose. In addition, to the extent that the bar of an authorized translation has greater scope in states with more than one national language, the rule operates to discriminate against those states.

\section{Conditions Precedent: The License Applicant's Burdens}

If the conditions which must exist prior to the application of the licensing statute are met, these are still certain duties incumbent on the licensee which must be satisfied before a compulsory license may be issued:

[The applicant must establish] either that he has requested, and been denied, authorization by the proprietor of the right of translation, or that, after due diligence on his part, he was unable to find the owner of the right.

Thus, the treaty provides that an applicant for a license must first request permission to make an authorized translation. If his requests are "denied," then a compulsory license may be granted. ${ }^{25}$ Accordingly, since the author's refusal to authorize a translation is a condition precedent to the issuance of a compulsory license, it would at first appear that the author will have a substantial opportunity, even after the seven years, to negotiate with prospective licensees concerning the terms of such a license. . On the other hand, if this condition precedent can be satisfied by something less than the author's absolute denial, then his rights may be considerably less significant. For example, it is possible that the author, though willing to authorize a translation, may not do so because of an impasse reached in the negotiations, perhaps caused by the unreasonableness of the applicant. Arguably, from the point of view of the licensing state, this is as much a "denial" as if it were absolute, since the result is equally to prevent a translation by means other than licensing. That the eventual interpretation of the clause will accord with this viewpoint is suggested by the fact that the Convention

${ }^{25}$ The original draft set the requirement in the following words: "in default of agreement with the author." The annex to the draft article reads: "[the license applicant] is unable to reach an agreement with [the author]." 
refused to adopt a proposal which would, have prevented licensing if the author's refusal to authorize a translation was "legitimate." In addition, the wording of the French and Spanish drafts support this position. ${ }^{27}$ It would, thus, appear that, whatever the cause, if the negotia. tions between the author and the applicant do not result in an authorization to translate, the licensing procedure may be invoked. ${ }^{28}$ Therefore, simply by bad faith negotiations, a license applicant could avoid direct dealing with the author, and probably thus effect a saving in royalty rates. ${ }^{29}$ In short, this provision is not likely to permit the author to participate extensively in arranging the terms for translations published after the seven-year period.

As an alternative to the requirement that the applicant meet with a denial from the author, the treaty provides that a compulsory license may issue if the owner of the right of translation cannot be located by "due diligence."30 A preliminary inquiry into the purpose of requiring an attempt at author contact is relevant. Since the author, if found, would have no substantial bargaining power, it is clear that, for negotiation purposes, there is little reason for any but nominal compliance by the applicant with this "due diligence" requirement. ${ }^{31}$ However, contact with the author serves purposes independent of insuring an opportunity to bargain. For example, by apprising the prospective

\footnotetext{
${ }^{20}$ Belgium proposed that a license should be obtainable unless the author "presents a legitimate opposition. The legitinacy of this opposition shall be judged by [a given international organism]." 6 UNESCO COPYRIGHT Bull. no. $x$, p. $2 x$ (xg53).

27 The French draft reads "ou obtenir son autorisation." The Spanish draft is in the same vein: "no pudo localizar al titular del derecho u obtenir su autorizacion."

${ }^{28}$ The only power of the author under the Convention to frustrate the licensing procedure is the provision that a license shall not be granted when the author has withdrawn from circulation all copies of the work. See the last sentence of article V, note 13 supra.

${ }^{20}$ See text to note 50 infra.

30 Neither the original draft nor its annex contained a "due diligence" test; but, instead, both required the applicant to make "all reasonable efforts to establish contact with the author" for a period of one year, prior to which time no license could be granted. In the final draft the "all reasonable efforts" test replaced the "due diligence" test, and the time requirement was reduced from one year to two months. See note $3 x$ infra.

31 The Convention specifies that a license shall not be issued until the expiration of two months from the date that copies of the application are sent to the enumerated sources provided for author contact. The object of this provision wa probably to save the author an opportunity to bargain with the applicant prior to the issuance of the license. In light of the construction likely to be given the term "denial," this provision is perhaps a bit optimistic.
} 
licensee of the author's whereabouts, it facilitates transmittal of compensation and insures that the licensee will be bound by notice of the location of the author in case the compensation is not forthcoming. ${ }^{32}$

These purposes are likewise served by a further provision of the treaty, which covers cases in which the author cannot be located after a search of "due diligence":

If the owner of the right of translation cannot be found, then the applicant for a licence shall send copies of his application to the publisher, whose name appears on the work and, if the nationality of the owner of the right of translation is known, to the diplomatic or consular represenative of the state of which such owner is a national, or to the organization which may have I been designated by the government of that state. ${ }^{33}$

In addition, this latter provision may give some indication of what efforts will satisfy the requirement of "due diligence." Most searches can probably be completed with a minimum of effort, but, because copyrights are separable ${ }^{34}$ and assignable, ${ }^{35}$ and because a substantial interval

\footnotetext{
${ }^{32}$ When an author is not located and the local publisher sells the translated work under a compulsory license, a serious problem would be presented if the author later appeared, demanding compensation. By the unqualified words "shall pay," the treaty appears to settle in the affirmative any doubt on the issue as to whether the author is entitled to compensation; but the intervals of time between the clate of first publication, the issuance of the license and when the owner appears may be crucial. Since the treaty does not require any state to protect foreign copyright for a period of longer than twenty-five years from the date of first publication, it might be contended that if the owner appeared after that interval he would no longer be entitled to compensation. This reasoning is unsound, however, because the duty to pay arose at a time when the author was protected. The problem may well be settled in the legislation which is necessary to implement the licensing system, for the statutes are likely to fix a period of limitations beyond which the owner will not be allowed to demand payment. The treaty fixes an absolute duty to pay, but this statutory period would probably be valid if the limitation was for a reasonably long period of time. If no provision is made in the licensing legislation, the question would then be determined under local statutes of limitations, which would be subject to the same standard of reasonableness.

${ }^{33}$ These enumerated sources of contact with the owner of the right of translation were not in the original draft of the article nor in its annex. The wording was adopted in toto from a combined proposal submitted by the states of Italy, Mexico, the United Kingdom, and the United States. 6 UNESCO COPYRIGHT BULL. no. 1, pp. 21-22 (1953).

${ }^{34}$ Translation rights are separable in that the author frequently transfers to his publisher the right to sell and place a translation, while the author retains the right
} 
may have elapsed between the time of publication and the application for license, it may be extremely difficult in many cases for an applicant to locate the owner of the right of translation. On the one hand, it might be argued that the applicant should exercise even greater efforts in these cases of especial difficulty. On the other hand, however, since certain means of contact are specifically provided by this last quoted provision, a more realistic solution would be to refer all but the simplest contact problems to these channels, deeming "due diligence" thus satisfied.

\section{The Nature of the License: The Nonexclusive and Nontransferable Limitations}

The conditions for the granting of the license having been satisfied, the treaty places two important limitations upon the license issued: that it be nonexclusive ${ }^{36}$ and nontransferable. ${ }^{37}$

The term "nonexclusive" has acquired a well-recognized meaning. It grants to the licensee merely a privilege to publish without incurring liability for infringement, and implies no right to exclude others from publishing. ${ }^{38}$ However, since one of the primary purposes of copyright laws is protection of the publisher from competition in order that he may profitably distribute his work, a licensing state may, for the same reason, extend to its compulsory licensees protection against other translators. Such protection does not seem objectionable in so far as it would enable the licensee to maintain an infringement proceeding against pirating translators; ${ }^{39}$ but it is plain that the licensing state

to receive compensation from the translation so placed. See UNWIN, THE TRUTH About Publishing 79 (5th ed. 1947 ).

${ }^{35}$ On copyright assignments, see generally BALL, THE LAW OF CoPYRIGHT AND Literary PROPERTY 532 (I944).

${ }^{36}$ The term "nonexclusive" was used in the annex to the original draft, but not in the original draft itself. It was not employed in the text of the drafting committee for the final draft, but was incorporated by the Convention in its Plenary Session. 6 UNESCO COPYRIGHT BULL. no. I, p. 23 (1953).

${ }^{37}$ The "nontransferable" restriction was not included in either the original draft or its annex. It was, however, later proposed by France and incorporated into the final draft. Id. at 22 .

${ }^{38}$ One writer likens the nonexclusive license to an easement to cross another's land, in the sense that the possessor of the easement cannot prevent others from crossing the land of the same owner. Ball, op. cit. supra note 38 , at 530 .

${ }^{30}$ Although under United States law, a nonexclusive licensee does not have the power to enjoin an unauthorized user from infringement, Birseld v. Shaliol, I 12 U.S. 485 (1884), there is no good reason to deny such a power to a compulsory licensee under the treaty. The licensee has an important economic stake in his translation, a 
could not, without violating the treaty, allow the publisher to proceed against authorized translators.

The second restriction, that the license be "nontransferable," discriminates against private persons as opposed to commercial publishers, since the former are normally in no position to benefit from the right otherwise than by transferring it. This discrimination, tending as it does to insure eventual publication under the license, is beneficial to the licensing state as well as to the author and, thus, clearly advances the underlying purposes of the treaty. ${ }^{0}$ However, in case the licensee fails to exercise his right by publication, it seems that the nontransfer provision would necessitate the issuance of another compulsory license by the licensing state. Because of the financial condition of publishing firms in most absorbing states, ${ }^{41}$ such a contingency is not unlikely; but a requirement that the local authorities confer licenses only upon reliable publishers would perhaps be too onerous a burden. In this respect, therefore, the nontransfer provision seems unavoidably adverse to the interests of the absorbing states.

Both of these restrictions tend to preserve, as much as possible, the potential market value of the author's continuing power to sell his translation rights. This tendency would definitely be counteracted if a licensing state were to adopt a policy of issuing more than one compulsory license for a single work; but the treaty itself does not forbid granting two or more licenses, unless exceptional emphasis is placed upon the article in the clause "may issue $a$ license."*2 However, the underlying policy favoring the needs of underdeveloped states does not argue strongly for the issuance of multiple licenses, provided the nontransferability provision effectively assures publication. If it becomes apparent, though, that the first compulsory license will not eventuate in a published translation, then the issuance of a second license would probably be desirable. In such a case, a scrupulous regard for

stake in which the author shares and which becomes more valuable if unauthorized competition can be forestalled.

${ }^{10}$ Because the nontransfer provision limits the applicants for licenses to publishers, as opposed to private individuals, the restriction that only nationals of the licensing state can apply is not unfairly discriminatory, since publishers would usually be locally domiciled.

${ }^{11}$ Because publishing firms in underdeveloped countries are typically undercapitalized and in precarious financial circumstances, several states proposed that the applicant show proof of his solvency and give security sufficient to guarantee compliance with the obligations of the license.

${ }^{12}$ See note I 3 supra. 
the policies underlying the treaty might lead to a practice of terminating the first compulsory license upon issuance of the second. ${ }^{43}$

\section{The Obligations of the Licensee and the Licensing State}

Not only is the license, once issued, of a restricted nature, but it also carries with it certain incidents designed to protect the rights of the author. The relevant provisions are:

Due provision shall be made by domestic legislation to assure to the owner of the right of translation a compensation which is just and conforms to international standards, to assure payment and transmittal of such compenșation, and to assure a correct translation of the work.

The original title and the name of the author of the work shall be printed on all copies of the published translation.

The provision requiring a "correct"44 translation of the work is of especial importance, since the author has no opportunity to choose his translator; but it is difficult to ascertain the precise meaning of this requirement. This difficulty stems from the fact that, heretofore, the only widely recognized international criterion for regulating the accuracy or quality ${ }^{45}$ of a translation was the "moral right" concept, which forbade the deformation, mutilation, or modification of a work to the prejudice of the author. ${ }^{46}$ Conceivably, the "correct" translation standard affords an even broader protection, since, literally, it forbids any

\footnotetext{
${ }^{4}$ The treaty makes no provision for termination of licenses once issued. See note 21 supra. However, the licensing state could terminate a license for any reason it deemed appropriate, since the license is not protected under the treaty.

14 The original draft of article V used the term "correct" translation as does the final draft. The draft annex to the article went further and required the applicant to "take all precautions for assuring respect for the character of the work and for its integrity by means of a correct translation." 4 UNESCO COPYRIGHT BULL, no. 3, pp. 9, 15 (1951).

${ }^{45}$ The quality of a translation, while important to an author, is not of a justiciable nature, and the law wisely does not require an affirmative standard of quality.

"The "Inoral rights" doctrine is firmly established in the copyright laws of the European countries, but is entirely absent from United States copyright law. See Roeder, The Doctrine of Moral Right: A Study in the Law of Artists, Authors, and Creators, 53 Harv. L. Rev. 554 (r940); Kat\%, The Doctrine of Moral Right and Amrrican Coskyright Law: A Proposal, 4 A.S.C.A.P. Copyright LaW Symposium 79 (1952); Stevenson, Moral Right and the Gommon Law: A Proposal, 6 A.S.C.A.P. Coryright LAW SYMPosium 89 (1955). The doctrine was incorporated into the Berne Union by the Rome Revision of 1928 , article 6 . See LADAs, The InTERnational Protection of Iliterary and Artistic Property $58 x$ ( $x 938$ ).
} 
liberties whatsoever with the author's expression, regardless of whether the inaccuracies are substantial enough to be prejudicial. ${ }^{47}$ On the other hand, it may be interpreted as less restrictive than the "moral right" standard, since, literally, it does not forbid abridgements or indiscriminate omissions, so long as what is translated is "correct." The fact that certain of the signatory nations, including the United States, have not yet adopted the "moral right" standard" ${ }^{48}$ may indicate that the drafters intended a less restrictive criterion. If so, however, the compromise choice of the term "correct," with its inherent vagueness, leaves it hardly certain that this provision will afford the author adequate protection against disfigurement of his product through translation.

The second, and most important, obligation which the treaty imposes on a licensing state is the requirement that the author be paid a "just" compensation which "conforms to international standards." phraseology of this provision reflects an unusually acute conflict between the interests of the absorbing and producing states. Because of the generally lower standards of living in the licensing countries, the compensation paid the author must bear a reasonable relation to the prevailing economic conditions there. Accordingly, since local sales are an important gauge of local conditions, it was suggested that a fixed royalty rate of five per cent be adopted as the uniform measure of compensation. ${ }^{50}$ This suggestion, however, ignored the fact that there are other aspects of local conditions which have a bearing on the ability of the licensee to pay. For example, the cost of publication, the cost of translation, and the saleability of different types of works ${ }^{51}$ within the same country are variables of considerable magnitude, and should be recognized by any standard adopted. In this respect, the provision that the compensation be "just" seems sufficiently flexible to accommodate all of these considerations.

On the other hand, the interests of the producing states quite

${ }^{47}$ In light of the purpose of the provision, it is highly doubtful that the author would be allowed successfully to object to inaccuracies unless the translation as such could reasonably be said to prejudice him.

${ }^{48}$ See note 46 supra.

${ }^{10}$ This terminology was suggested in a combined proposal by Italy, Mexico, the United Kingdom, and the United States. 6 UNESCO COPYRIGHT Bull. no. 1, pp. 2 122 (1953).

${ }^{50}$ This proposal was submitted by the Canadian delegation. Ibid.

"Compare, for example, these different factors as they would influence the cost of publication of a translation of a short novel and a medical textbook. 
clearly require that there be some minimum standard of compensation which must be met by even the poorest licensing state. This minimum protection will probably be afforded by the "international standards" criterion finally adopted by the Convention. ${ }^{52}$

In addition to this minimum standard of compensation, the treaty imposes one further obligation: that the compensation, so measured, be actually "transmitted" to the author. It would be useless, of course, to provide for just compensation if exchange into the currency of the producing state is to be blocked by the licensing state; and it is clear that the countries most interested in compulsory licensing are economically, as well as culturally, absorbing.

Consequently, currency blockade of copyright compensation is a real problem. ${ }^{53}$ But this prophylactic provision, though well aimed, perhaps lacks the specificity necessary fully to accomplish its purpose. For example, while the transmission of only the currency of the licensing state might violate the spirit of the treaty, it might well not be considered prohibited by the letter of the clause. Further specification, ${ }^{54}$

"The reference to "international standards" apparently incorporates the international law concept of an international standard of justice by which every state has a duty to accord to aliens and their property the minimum standards of justice recognized by all civilized states of the world. See generally WiLson, THE INTERNational LaW Standard in Treaties of THE UNited STATES (1953). A basic tenet of this concept is that the international, rather than the local standard is applicable. Thus less advanced states are deterred from attempting to justify their actions on grounds of local standards,

${ }^{63}$ One theory advanced by some states to justify the blockade of copyright payments is that such payments are an export of currency not offset by a corresponding import. del Castillo, Copyright and the Use of Foreign Works, 3 UNESCO COPYRIGHT BULL. no. I, pp. I3, I6 (1950). But since a property right is, in fact, transferred, such an argument seems untenable. In terms of economic realities, the value which the state receives through diffusion of culture would seem to require that copyright payments be placed on a priority list. From the point of view of the author also, it appears imperative that a currency exchange be required. When realty of an alien is condemned by the situs state and compensation is paid only in local currency, the element of inconvenience in utilizing that currency may be reduced, because persons who own land in a foreign country often have contacts with that state and may better be able to make use of the currency. Unlike the real estate proprietor, however, a copyright proprietor probably has no connection with the foreign state, and thus the currency is of very little value to him.

"For example, the provision could have been worded "payment to be made in the currency of the state of the owner of the right of translation." Recent provisions in United States bilateral commercial treaties reveal such a trend toward specification. While there is general wording that compensation for expropriation of property of nationals of the contracting states shall be "prompt, just and effective," or made in "an effectively realizable form," there are provisions that expressly set out rules to be 
then, seems desirable; but the present provision will probably accomplish much in solving the exchange blockade problem.

\section{Regulation of Sale of Licensed Translations \\ Outside the Licensing State}

Since a number of countries have the same national language, as in South America and in the Middle East, some provision regarding the sale of licensed translations outside the licensing state was considered essential. Accordingly, the treaty contains the following provision:

The license shall be valid only for publication of the translation in the territory of the Contracting State where it has been applied for. Copies so published may be imported and sold in another Contracting State if one of the national languages of such other state is the same language as that into which the work has been so translated, and if the domestic law in such other state makes provision for such licences and does not prohibit such importation and sale. Where the foregoing provisions do not exist, the importation and sale of such copies in a Contracting State shall be governed by its domestic law and its agreements. ${ }^{.5}$

This clause prescribes essentially three conditions which must be met before a licensed translation may be sold in another country. The importing country must be a party to the Convention; it must have the same national language; and it must not prohibit the importation and sale by its "domestic law and its agreements." The third requirement is obviously the most significant and requires a survey of the situations in which a prospective importing state may adopt such a prohibition..$^{56}$

First, if the importing state has a licensing statute under which a

followed limiting the timing and percentage of exchange withdrawals. See Wilson, Property-Protection Provisions in United States Commercial Treaties, 45 AM. J. INT's. L. 83 , 100 (1951).

${ }^{5}$ These sales provisions were not a part of the earlier drafts of the article, but were incorporated into the final draft at the Plenary Session of the Convention when proposed by France, Mexico, the United Kingdom, and the United States. See report of the Rapporteur Général in 5 UNESCO CopYright BulL. no. 3, p. 54 (1952).

${ }^{50} \mathrm{~A}$ state may prohibit such importation and sale for several reasons. However, the language used in the provision expressly negates any possibility of a claim that the licensing state has a "right" to such importation and sale. The implication of such a right would raise questions concerning most-favored-nation clauses in tariff treaties. 
license has been granted for the work in question, that state will undoubtedly have made provision to protect the locally licensed translation. Second, if subsequent to the granting of the original license in the exporting state, the author has authorized a translation in the importing state, the latter state will protect the locally authorized transIator. Third, the importing state may be bound by a treaty "agreement," such as the Berne Union or the Pan-American Convention, under which protection of the author's right of translation may be required.57

The most troublesome situation occurs where the importing state has no licensing statute and is not bound to the author's state by any agreement other than the UNESCO Convention. Conceivably, this Convention could be interpreted as an "agreement" which would require full protection of the author's right of translation by the importing state. The underlying policy of encouraging cultural diffusion, however, suggests that the better result would be to allow importation even by a state which has not felt the need for cultural absorption sufficiently to pass a licensing statute. Furthermore, since payments under the original license would probably be on a royalty basis, the author will receive some benefit for sales in the importing state.

\section{Evaluation and Conclusion}

With the exception of the unnecessary restriction concerning states with more than one national language, ${ }^{58}$ the provisions of the compulsory licensing system seem sufficient to satisfy the needs of underdeveloped countries. Consequently, the system will undoubtedly commend the UNESCO Convention to a wider range of prospective signatories.

From the author's point of view, however, the compulsory license provisions may be somewhat disadvantageous. First, the complete deprival of bargaining power after the expiration of the seven-year treaty period, coupled with the possibility of abuse by the agency charged with the administration of the licensing statute, substantially impairs the author's most vital interests. The ready answer to this criticism is that the author can protect himself by authorizing translations prior to the expiration of the seven years; but even this right is considerably restricted, since foreign publishers can frequently afford a seven-year delay. ${ }^{69}$

\footnotetext{
${ }^{67}$ See note 73 infra. $\quad{ }^{68}$ See text to note 25 supra.
}

${ }^{50}$ In the proceedings of the Washington Conference, the representative from India observed that, under Indian law, where the author's translation rights expire after 
While the objections on behalf of the authors may be well founded, the protection extended by this Convention is, nevertheless, greater than that which previously existed. Since the Convention does not abrogate existing international obligations, ${ }^{60}$ translation rights protected by such treaties will not be endangered. ${ }^{61}$ As to states with which there are no existing agreements, the minimum protection of article $\mathrm{V}$ is obviously a gain which inures to the benefit of the author.

In the main, then, the compromise position adopted by the Convention seems to strike a fair balance between the competing interests of the culturally producing and absorbing states. Legislation implementing the licensing provisions will probably not be widely adopted, but the value of the system to the underdeveloped states of the world is certainly likely to assure its permanence. ${ }^{62}$

ten years, the experience has been that local publishers would wait for the expiration of that period before making translations in order to avoid the necessity of dealing with the author. 3 UNESCO COPYRIGHT BULL. no. 3, p. 63 (1950).

${ }^{\circ 0}$ See note 4 supra. Although the United States is not a member of the Berne Convention, prudent authors and publishers in this country have previously received protection under that Convention by placing copies of a work for sale in Canada or England, which are member countries. Henn, The Quest for International Copyright Protection, 39 CORNELL L.Q. 43, 49 (1953). However, several recent decisions by Dutch courts have cast doubt on several aspects of the validity of this "back door protection" practice. Saher, American-Netherlands Copyright Problems, I Worud TRADE L.J. 371 (1946). While many publishers will continue to employ this practice in order to obtain the higher standards of protection under the Berne Union, it is possible that other courts may be inclined to deny this protection now that alternative international protection is available to our authors.

${ }^{01}$ The Berne Union requires full protection to be accorded to translation rights. See LADAS, op. cit. suppra note 5, at 377 . The period of full protection is fifty years after the death of the author. Id. at 145. The Buenos Aires Convention, the most important of the Pan-American treaties, does not stipulate the duration of protection which must be granted translation rights, and the treaty is construed to require only national treatment. Todamerica Musica, Ltda. v. Radio Corporation of Americi, $17 \mathrm{I}$ F.2d 369 (2d Cir. 1948); Portuondo v. Columbia Phonograph Co., 81 F. Supp. 355 (S.D.N.Y. 1937). Since local restriction of translation rights is prejudicial only to foreign copyright holders, some signatories of the Buenos Aires Convention have shortened considerably the duration of protection of this right. [E.g., Mexico. See note 12 supra.] The UNESCO Convention, in thus setting a minimum base of protection is more advantageous to American authors than that which existed previously. Henn, Interrelation between the Universal Copyright Convention and the Pan-Americant Conventions, 2 BULL. CoPY. SOC. IIo (1955).

${ }^{02}$ Finkelstein, The Right of Translation, id. at 96, 99. To date no state is known to have passed licensing legislation. 